\title{
The Impact of IFRS Adoption on Quality of Accounting Information: Evidence from Sri Lanka
}

\author{
Yasas T.G ${ }^{1}$ and Perera H.A.P.L ${ }^{2}$ \\ Department of Accountancy \\ University of Kelaniya, Sri Lanka \\ ygamage1@gmail.com ${ }^{1}$ and prabathperera@kln.ac.lk²
}

\begin{abstract}
The aim of this study is to examine the effect of International Financial Reporting Standards (IFRS) adoption on quality of accounting information in terms of value relevance of listed manufacturing companies in Colombo Stock Exchange. At present, countries are mandated or permitted to apply IFRS in preparation of their financial statements. There are many studies available on IFRS adoption internationally. However, there is no clear evidence that IFRS adoption enhances the quality of accounting information pertaining to Sri Lankan context. This study employs 29 listed manufacturing companies with both pre-IFRS (2009-2011) and post-IFRS (2013-2015) information. Data were analyzed using multiple regression method. Results showed that value relevance of accounting information has not significantly improved in the post-IFRS period than the pre-IFRS period. Further studies are encouraged to conduct on investigating the impact of IFRS adoption on the quality of accounting information by expanding the sample size.
\end{abstract}

Keywords: IFRS adoption, Accounting quality, Value relevance, Sri Lanka, Manufacturing companies

Copyright: (c) 2019 Yasas T.G., Perera H.A.P.L. This is an open access article distributed under the Creative Commons Attribution License, which permits unrestricted use, distribution, and reproduction in any medium, provided the original work is properly cited.

Correspondence: prabathperera@kln.ac.lk

ORCID of authors: Yasas T.G. - - (iD https://orcid.org/0000-0001-5431-6965

Perera H.A.P.L. - (iD https://orcid.org/0000-0003-3282-8710

DOI: http://doi.org/10.4038/kjm.v8i1.7566 


\section{Introduction}

\section{Background of the Study}

Accounting standards are a set of principles and guidelines which should be followed by companies in preparing and publishing their financial information periodically. Accounting standards will provide a consistent way of presenting the monetary performance of the company. Listed entities are legally bound to prepare and publish their financial information according to a given set of accounting standards (IFRS Foundation, 2017).

Adopting IFRS will be beneficial in numerous ways such as; facilitating crossborder transactions across the globe, enhancing free flow of international capital and also helping the investors to seek diversification and providing investment opportunities across countries as well as being a source to reduce the information asymmetry plus uncertainty and thereby reducing transaction costs to a large extent (Ball, 2006; Devalle et al., 2010; Iatridis, 2010; IFRS Foundation, 2017; JenicePrather-Kinsey, 2005; Olfa and Hamadi, 2015; Tendeloo and Vanstraelen, 2005).

\section{IFRS adoption in Sri Lankan Context}

All the listed companies in Colombo Stock Exchange were mandated to adopt Sri Lankan Financial Reporting Standards (SLFRS) which is very much identical to International Financial Reporting Standards (IFRS) with effect from 1st January 2012 (Weerathunga and Udaya Kumara, 2015). An Extraordinary Gazette (No.1735/25) was passed by The Institute of Chartered Accountants of Sri Lanka on December 2011, which contains all the relevant details about the standards which were replaced (Sri Lankan Accounting Standards (SLAS) were used earlier before the adoption) by LKAS as well as SLFRS/IFRS.

\section{Research Problem}

The adoption of a different set of accounting standards such as IFRS will change the presentation and the content of financial information in the financial statements. This will lead a significant change in the quality of accounting information. Therefore, many studies were conducted in the world to discover the impact of IFRS adoption on quality of accounting information.

With referring to Sri Lanka's IFRS adoption in 2012, the accounting standards were changed from SLAS to LKAS and SLFRS. Those standard are very much identical to International Financial Reporting Standards (IFRS). With this adoption what is the impact on the quality of accounting information in terms of value relevance? Is there any significant impact on the quality accounting information? Whether there is any increase or decrease compared to previous set of accounting standards (SLAS)? In order to address above questions following research question was formulated.

"What is the impact of IFRS adoption on quality of accounting information in terms of value relevance?"

\section{Objectives of the Research}

The main objective of this research is to find out the impact of IFRS adoption on quality of accounting information in terms of value relevance on accounting information of listed manufacturing firms during the period of 2009 to 2015 . In addition to that, this study aims to find the relationship of IFRS adoption in Sri Lanka with the market price, earnings, equity and operating cash flow of the listed manufacturing companies. 


\section{Hypothesis Development}

In this study an attempt was made to find the Pre- and Post-impact of IFRS adoption on the value relevance of financial information. Outa, (2011) mentioned that value relevance attempts to associate a financial value as conveyed in stock prices to the reported balance sheet and income statement figures. The association between firm-specific information and share price should increase resulting in higher value relevance of accounting information after the post-IFRS adoption (Devalle et al., 2010). Therefore, the following hypothesis was tested in this study.

$\mathrm{H} 1$ = There is a significant change in the quality of accounting information in terms of value relevance reported under SLAS (pre-IFRS) compared to LKAS/SLFRS (post-IFRS).

\section{Significance of the Study}

According to Mulenga, (2016) even though there are plenty of empirical research conducted in matured financial markets, the emerging financial markets such as Colombo Stock Exchange (CSE) has been somewhat neglected thus the performance of an emerging stock market can also be retrieved. Nevertheless, there is plenty of literature on accessing accounting quality after IFRS convergence in the global context, when it comes to Sri Lankan context there are only handful researches conducted about examining the impact of IFRS adoption on accounting quality. This study will contribute to the existing literature by solely focusing on the most important dimension of accounting quality that is value relevance. According to Alfaraih, (2009) value relevance can be considered as the most important attribute of measuring accounting quality. This academic work will also be useful for the regulatory institutions as well as accounting standards-setting institutions such as Institute of Chartered Accountants of Sri Lanka (CASL) and also international bodies like International Accounting Standards Board (IASB). Both these organizations can evaluate the quality and performance of the recently introduced IFRS/SLFRS's, since if these standards are not up to the expected level, these institutes have an opportunity to amend these standards in the future. Also most importantly the end users of financial statements such as analysts, investors and other stakeholders can consider the impact of IFRS adoption on accounting quality while comparing the Pre and Post time periods.

\section{Literature Review}

\section{Quality of Accounting Information}

There were many studies conducted around the world regarding the impact of IFRS adoption on improving the quality of accounting information. Weerathunga and Udaya Kumara, (2015) mentioned that there is no clear definition of accounting quality. According to Lang et al., (2006) accounting quality can be measured using three aspects namely, earnings management, timely loss recognition and value relevance. This approach is followed by (Arum, 2013; Barth et al., 2008; Outa, 2011; Paglietti, 2010; Weerathunga and Udaya Kumara, 2015).

Earnings management can be considered as an attempt taken by management in the company to manipulate the economic and financial data which is reported in the financial statements and annual reports for the sake of their personal benefits and thereby misleading the stakeholders (Goel and Thakor, 2003; Healy and Wahlen, 1999). So the reduction in earnings management will provides higher quality of accounting information. 
On the other hand, timely loss recognition means that if managers see a loss that is nearly going to occur in the future relevant measures has to be taken at present rather than spreading it over future periods (Barth et al., 2008).Firms are said to be improved accounting quality if they display more timely loss recognition (Weerathunga and Udaya Kumara, 2015).

Value relevance is defined as "The ability of financial statement information to capture and summarize the value of the firm" (Suadiye, 2012). Apart from all other aspects for measuring the quality of accounting information, Value relevance can be considered as the most prominent basis of measurement since it delivers direct convenience of accounting information to the users in the capital market (Edward Lee, 2013; Kaaya, 2015). Therefore the researcher selected value relevance to measure the quality of accounting information.

In order to find whether IFRS adoption has improved the accounting quality, numerous researchers are conducted in countries in different regions. In United States, Ashbaugh and Pincus, (2001) studied whether the variances among local and international accounting standards can influence the financial analysts' forecasts of earnings and their study shows a positive as well as significant relationship between local GAAP-IFRS changes with analysts' forecasts of earnings.

Similarly another IFRS - GAAP comparison was conducted very recently by Samir M. El-Gazzar and Philip M. Finn, (2017) tried to identify whether the IFRS adoption in US would present the accounting information with the same quality as of those presented under US GAAP by incorporating a sample of foreign firms listed on US stock exchanges which follows IFRS compared to a sample of US firms which practice GAAP during 2001 to 2010 and observed that IFRS firms do have a lower restatement in contract to US GAAP firms as well as there were no substantial changes in the sources of restatements, influence on net income as well as market revaluations. These findings might indicate that there is no significant deviation between IFRS and US GAAP however it is a questionable fact.

Numerous Studies were accompanied in African region. Ames, (2013) studied about the impact of IFRS convergence on accounting quality in South Africa by considering 3950 firms for the period from 2000 to 2001 and came across with that the earnings quality is not significantly improved in the post IFRS adoption period. Similarly, according to Alabede et al., (2016) Nigeria applied IFRS in preparing financial statements with effect from 2012 and by using 67 non-financial companies which operates in Nigerian Stock Exchange for the period in between 2007 to 2014 they found that accounting information was value relevant but not significantly different after the IFRS adoption.

There were many studies conducted in the EU region for example, Paananen, (2008) inspected that whether the quality of accounting information has increased with the IFRS adoption of Sweden in 2005. He found that there has been no improvement in the financial reporting quality during the first two years after the IFRS adoption. Similarly, Hung, (2007) Inspected the effect of the voluntary adoption of IFRS by German listed firms in the period 1998 -2002 and reported that the adoption of IFRS did not improve the value relevance of book value or net income. Tendeloo and Vanstraelen, (2005) investigated whether German companies that have adopted IFRS engage less in earnings management motivation and their results claimed that high-quality accounting standards like IFRS could be a circumstance for highquality accounting information which can 
improve the value relevance of their financial statement information.

Morais and Curto, (2008) investigated whether adopting IASB standards is associated with higher earnings quality and higher value relevance by comparing the earnings quality and value relevance of accounting data of 34 Portuguese listed firms before (1995-2004) and after (20042005) the adoption of IASB standards. Their results suggested that an improvement in earnings quality while the value relevance of accounting information decreased with the adoption of IASB standards. Jermakowicz and GornikTomaszewski, (2006) examined the perceptions of European companies over IFRS, one year before their mandatory implementation and they found that the main expected benefit from the conversion to IFRS was the opportunity for better comparisons with other companies and the ability to have greater reporting transparency. On the contrary, the high cost of transition, the increased volatility of earnings, the change of the existing information systems, the complicated nature of particular standards and the need for continuous training of personnel, were identified as disadvantages.

Iatridis, (2010) focused on the adoption of the International Financial Reporting Standards (IFRSs) in the UK by examining company accounting measures reported under the UK GAAP and IFRSs, the study investigated the earnings management potential under IFRS which indicated that the implementation of IFRSs generally reinforces accounting quality. Chen et al., (2010) mentioned that previous studies on the effect of IFRS on accounting quality often hindered due to having difficulties in controlling the confounding factors on accounting quality, therefore they used unique research setting to address this issue by comparing the accounting quality of publicly listed companies in 15 member states of the European Union (EU) before and after the full adoption of IFRS in 2005 by using five indicators as proxies for accounting quality and they came across with as that the majority of accounting quality indicators were improved after IFRS adoption in the EU. According to Callao et al., (2007) the mandatory adoption of IFRS in Spain with reference to IFRS application in EU had aggravated the local comparability of financial statement information and mentioned in addition that the local comparability would adversely affected if both IFRS and local accounting standards are applied in the same country at the same time. They highlight the fact that the gap between book and market values become wider when IFRS's are applied.

Papadatos and Bellas, (2011) compared the value relevance of accounting information under International Financial Reporting Accounting standards (IFRS) and Greek Accounting Standards (GAS) and they investigated whether the results are influenced from firm specific characteristics and showed that both firm size and fixed assets become significant factors, implying that the consequences of the mandatory transition to IFRS may not be the same for all firms. Similarly, Karampinis and Hevas, (2009) tested the effect of mandatory adoption of IFRS on value relevance of earnings and book values using data from Athens stock exchange for a period of two years before and after and they concluded that IFRS adoption positively affect the value relevance of Consolidated net income and book value of equity. But according to Tsalavoutas et al., (2012) the combined book value of equity and net income before and after IFRS transition has not been significantly changed between the two periods Cascino and Gassen, (2010) investigated the effects of mandatory IFRS adoption on the comparability of financial accounting information around 
the world using a sample of German and Italian firms and their results suggested that while mandatory adoption of IFRS increases the comparability of some leading balance sheet line items across countries, it has no clear effect on the cross-country comparability of earnings attributes and thereby suggested that the mandatory adoption of IFRS has a limited impact on accounting comparability.

When considering about the studies conducted in the Asian region especially in China, before 2007 in order to boost global investment china had used two similar accounting arrangements. The first one is rest on Chinese GAAP which is solely for local shareholders and the other one is based on IFRS which is for International shareholders. After 2007 transformation these two sets were substituted by a single set of standards.

Qu et al., (2012) observed that the China's 2007 IFRS convergence from Chinese GAAP has heightened the quality of accounting information for investors in the A-share market in China. They analyzed investor's reaction to financial information released both pre and post IFRS convergence in China from a sample of data from 309 listed Chinese companies using multiple regression analysis. They came across with that the earnings per share, relative to book value of equity, is a stronger explanatory factor of market return in both before and after IFRS convergence periods and thereby proposing that stockholders believe deeply upon earnings disclosed by quoted companies when making security price decisions in the Chinese share market. Also, they proposed that investors' trust on the income statement information for investment choices becomes greater in the post-IFRS convergence period.

\section{Studies on IFRS adoption in Sri Lanka}

Even though many kinds of research been conducted various countries across the world regarding the IFRS adoption and its impact, only a handful of research were conducted in Sri Lanka. For example Weerathunga and Udaya Kumara, (2015) examined whether the adoption of International Financial Reporting Standards (IFRS) is associated with higher accounting quality for Sri Lankan firms using a sample of 157 firms listed in Colombo Stock Exchange (CSE) while referring to earnings smoothing, managing towards earnings targets, timely loss recognition and value relevance. Their overall results indicate that in general, accounting quality of Sri Lankan firms is improved after fully adoption of IFRS in terms of displaying less management towards earnings targets and more timeliness of loss recognition. On the other hand, they found that there is no evidence on the improvement of accounting quality has been improved with regards to reducing earnings smoothing and improving value relevance. And on the other hand, foreign researchers like Shima and Yang, (2012), Brüggemann et al., (2012) Ben Othman and Kossentini, (2015) incorporated Sri Lanka with other countries in their analysis.

\section{Methodology}

\section{Conceptual Framework}

Depending on the literature, the measurement of accounting quality was executed in terms of improvement in value relevance. For this purpose, several researchers used the Ohlson model. Accounting information is said to be value relevant if this model displays a higher adjusted R-value. (Erin et al., 2017); (Qu et al., 2012); (Kaaya, 2015). For this study the model suggested by Qu et al., (2012) will be applied.

This can be further explained by a regression equation, 


$$
\mathrm{MPS}_{i t+6}=\beta_{0}+\beta_{1} \mathrm{EPS}_{i t}+\beta_{2} \mathrm{BVE}_{i t}+
$$$$
\beta_{3} \mathrm{LEV}_{i t}+\beta_{4} \mathrm{OCF}_{i t}+\varepsilon_{i t}
$$

Whereas,

- $\quad \mathrm{MPS}_{i t+6}=$ Closing price of a share for the company $i$ in time $t+6$ (six months after the financial period end which is the time where annual financial statements were made available for general public );

- $\mathrm{EPS}_{i t}=$ Earnings per share of the company $i$ in time $t$;

- $\mathrm{BVE}_{i t}=$ Book value of equity per share of the company $i$ in time $t$;

- $\mathrm{LEV}_{i t}=$ Ratio of debt to equity (Leverage/Gearing) ratio for the company $i$ in time $t$;

- $\mathrm{OCF}_{i t}=$ Net operating cash flow per share for the company $i$ in time $t$;

- $\beta 0=$ Constant term;

- $\quad \beta 1-\beta 4=$ Coefficients of the independent variables used in the regression model.

Note: LEV is used as a control variable

This model can be further expanded by incorporating the effect of IFRS adoption through a dummy variable "IMPACT", where the IMPACT becomes " 0 " for the pre-IFRS period and " 1 " for post-IFRS period. This variable can be multiplied by independent variables EPS, BVE, OCF and then the impact of IFRS adoption on individual variables can be obtained to find the association with the market price of the share. The equation was reestimated as follows,

$\operatorname{MPS}_{i t+6}=\beta_{0}+\beta_{1} \mathrm{EPS}_{i t}+\beta_{2} \mathrm{BVE}_{i t}+\beta_{3} \mathrm{LEV}_{i t}+$ $\beta_{4} \mathrm{OCF}_{i t}+\mathrm{IMPACT}^{*} \mathrm{EPS}_{i t}+$

$\mathrm{IMPACT}^{*} \mathrm{BVE}_{i t}+\mathrm{IMPACT}^{*} \mathrm{OCF}_{i t}+\varepsilon_{i t}$ (2)

\section{Population and Sample Selection}

To find whether the IFRS convergence in Sri Lanka was able to improve the quality of accounting information, secondary data was obtained from the listed entities in
Colombo stock exchange (CSE). Since all domestic companies whose securities are traded in an open market has a requirement of preparing financial statements using Sri Lankan Accounting Standards (SLAS) which was replaced by Sri Lankan Financial Reporting Standards (SLFRS). As we mentioned earlier in this paper, these SLFRSs are identical to IFRSs with effect from $1^{\text {st }}$ January 2012.

There were 296 companies listed in CSE representing 20 business sectors as at 31 of August 2017. This can be considered as the total population for this research. Among aforesaid 20 sectors, manufacturing sector was selected for this study as the sample. The main reason to select the manufacturing sector was the lack of literature in srilankan context

On the other hand when it comes to the composition of the CSE sectors in terms of the number of listed companies, Banking Finance and Insurance sector is the sector which consists most number of companies with 63 listed companies in total and manufacturing sector comes in second place consisting 38 listed companies in total. Banking Finance and Insurance sector cannot be taken for this analysis since the regulations and reporting are totally different and these organizations are closely regulated and supervised by Central bank of Sri Lanka, Insurance board of Sri Lanka by imposing several rules and regulations. The accounting quality of these companies may be higher than other companies even prior to the mandatory adoption of IFRS (Weerathunga and Udaya Kumara, 2015). There were 38 companies listed under manufacturing sector in CSE as at $31^{\text {st }}$ August 2017. Among those 38 listed companies in the manufacturing sector 5 companies were excluded because those companies were listed in CSE after IFRS adoption which is after 2012/01/01 and 2 companies were omitted due to unavailability of data and 2 companies 
were excluded due to non-adaptation of IFRS in preparing their financial statements. Thus, the final sample consists of 29 Listed Companies.

To find out the improvement in accounting quality our analysis was divided into both pre- IFRS and post IFRS. Since Sri Lanka has adopted IFRS with effective from $1^{\text {st }}$ January 2012 onwards, the analysis was divided into 2 phases whereby $1^{\text {st }}$ phase was named as "Pre- IFRS Period" ranging from 2009 to 2011 and the $2^{\text {nd }}$ phase was named as "Post -IFRS Period" expanding from 2013 to 2015. Since 2012 was the transition year it was excluded from the study and finally, this analysis consists of 203 firmyear observations in total.

\section{Data Analysis Techniques}

Obtained data were grouped into two panels namely pre-IFRS and post-IFRS data. Regression models were used by using panel data analysis.

As the preliminary step, the model was converted to logarithmic form to address the non-normality issue and the model was re-estimated as follows,

$$
\begin{aligned}
& \log \mathrm{MPS}_{i t+6}=\beta_{0}+\log \beta_{1} \mathrm{EPS}_{i t}+ \\
& \beta_{2} \log \mathrm{BVE}_{i t}+\beta_{3} \log \mathrm{LEV}_{i t}+\beta_{4} \log \mathrm{OCF}_{i t}+ \\
& \varepsilon_{i t}
\end{aligned}
$$

$\log _{\text {MPS }} i t+6=\beta_{0}+\beta_{1} \log \mathrm{EPS}_{i t}+$ $\beta_{2} \log \mathrm{BVE}_{i t}+\beta_{3} \log \mathrm{LEV}_{i t}+$ $\beta_{4} \log \mathrm{OCF}_{i t}+\mathrm{IMPACT}^{*} \log \mathrm{EPS}_{i t}+$ $\mathrm{IMPACT}^{*} \log \mathrm{BVE}_{i t}+\mathrm{IMPACT}^{*} \log$ $\mathrm{OCF}_{i t}+\varepsilon_{i t}$

\section{Findings and Discussion}

\section{Descriptive statistics}

Descriptive Statistic summary tables were obtained for the pre-IFRS and post-IFRS data samples which are summarized in two tables, Table 1 and Table 2 (Appendix $\mathrm{A}$ and $\mathrm{B})$.
Table 1 and 2 shows mean, median, maximum and minimum, standard deviation for 87-panel data observations for 29 listed manufacturing companies in both pre and post IFRS periods. The mean value for LOG (MVPS) has been slightly decreased in the post-IFRS period compared to pre-IFRS period by $3 \%$. When observing the behavior of the independent variables both the mean values for LOG (EPS) and LOG (BVE) has been increased but the value decreased for LOG (OCF) and LOG (LEV). The median values for LOG (MVPS), LOG (EPS), LOG (BVE) and LOG (LEV) has been increased in the post-IFRS period compared to the pre-IFRS period but it decreased for LOG (OCF).

Table 3 (Appendix C) explains the descriptive statistics for 29 listed manufacturing companies from year 2009 to 2015 . It combines the pre and post IFRS periods into one model. The mean value for LOG (MVPS) computed as 3.78 and the maximum and minimum values for LOG (MVPS) ranges from 5.9 to 0.37 with a standard deviation of 1.18 . Whereas the median value of LOG (MVPS) showed as 4. The mean LOG (EPS) value was 0.77 for the sample and which has a median value of 0.92 with a standard deviation of 1.73. The Mean value of LOG (BVE) was 3.13 and had a median of 3.41 and a standard deviation of 1.31. LOG (LEV) value showed a negative mean value of 1.42. This denoted very low value of leverage ratios for listed manufacturing companies. Listed manufacturing companies in Sri Lanka tend to keep a very low leverage ratio during the period of 2009-2015.

One of the most important variable in this descriptive statistic table is the "IMPACT" variable. The mean value of "IMPACT" is 0.44 or $44 \%$,means that out of total 203 observations, 89 observations were inclusive of IFRS adoption (postIFRS) as well as 114 observations were 
not inclusive of IFRS adoption (preIFRS).

\section{Panel data analysis}

\section{Model 01- Pre IFRS and Post- IFRS}

Pre-IFRS (2009-2011) and Post-IFRS (2013-2015) models has been obtained from Panel Estimated Generalized Least Squares method (Panel EGLS) referring to Cross section random effects.

Table 4 Summary of Regression result 2009-2011 (Model 01)

\begin{tabular}{|c|c|c|c|c|}
\hline Variable & Coefficient & Std. Error & t-S tatistic & Prob. \\
\hline $\mathbf{C}$ & 2.067155 & 0.283868 & 7.282098 & $\mathbf{0}$ \\
\hline LOG(EPS ) & 0.18737 & 0.046925 & 3.992947 & 0.0001 \\
\hline LOG(BVE) & 0.540353 & 0.092907 & 5.81608 & $\mathbf{0}$ \\
\hline LOG(LEV) & -0.003126 & 0.045704 & -0.068399 & 0.9456 \\
\hline $\begin{array}{c}\text { LOG(OCF } \\
)\end{array}$ & 0.022831 & 0.042758 & 0.533964 & 0.5948 \\
\hline & \multicolumn{2}{|c|}{ Effects S pecification } & & \\
\hline & & & S.D. & Rho \\
\hline \multicolumn{3}{|c|}{ Cross-section random } & 0.464533 & 0.5229 \\
\hline \multicolumn{3}{|c|}{ Idiosyncratic random } & 0.443759 & 0.4771 \\
\hline & \multicolumn{2}{|c|}{ Weighted S tatistics } & & \\
\hline R-squared & 0.561292 & \multicolumn{2}{|c|}{ Mean dependent var } & 1.8682 \\
\hline $\begin{array}{l}\text { Adjusted R- } \\
\text { squared }\end{array}$ & 0.539891 & \multicolumn{2}{|c|}{ S.D. dependent var } & 0.66682 \\
\hline $\begin{array}{l}\text { S.E. of } \\
\text { regression }\end{array}$ & 0.452311 & \multicolumn{2}{|c|}{ S um squared resid } & 16.776 \\
\hline F-statistic & 26.22809 & \multicolumn{2}{|c|}{ Durbin-Watson stat } & 2.14067 \\
\hline \multirow[t]{2}{*}{$\begin{array}{l}\text { Prob(F- } \\
\text { statistic) }\end{array}$} & $\mathbf{0}$ & & & \\
\hline & \multicolumn{2}{|c|}{ Unweighted S tatistics } & & \\
\hline R-squared & 0.689404 & \multicolumn{2}{|c|}{ Mean dependent var } & 3.86834 \\
\hline $\begin{array}{l}\text { Sum } \\
\text { squared } \\
\text { resid }\end{array}$ & 35.71045 & \multicolumn{2}{|c|}{ Durbin-Watson stat } & 1.43703 \\
\hline & & & & \\
\hline
\end{tabular}

Table 4 represents the model 01 summary computed for the period of 2009-2011. It contains 87 balanced observations. 29 cross sections were included in this summary. The weighted R squared for this model was $56.1 \%$ and the adjusted $\mathrm{R}$ squared was $54 \%$. According to the $\mathrm{F}$ statistic the overall model was statistically significant at $1 \%$ level. The DurbinWatson statistic of the model was 2.14, which is almost closer to 2. This implied that the model is free from autocorrelation. LOG (EPS) and LOG (BVE) variables were statistically significant at $1 \%$ level and both have a positive relationship with the LOG (MVPS). LOG (OCF)) and LOG (LEV) were not statistically significant.

Table 5 Summary of Regression result 2013-2015 (Model 01)

\begin{tabular}{|c|c|c|c|c|}
\hline Variable & Coefficient & Std. Error & t-S tatistic & Prob. \\
\hline $\mathbf{C}$ & 1.229372 & 0.333116 & 3.690524 & 0.0004 \\
\hline LOG(EPS) & 0.107152 & 0.046103 & 2.324203 & 0.0226 \\
\hline LOG(BVE) & 0.730746 & 0.103998 & 7.026523 & $\mathbf{0}$ \\
\hline LOG(LEV) & -0.023735 & 0.066376 & -0.357578 & 0.7216 \\
\hline $\begin{array}{c}\text { LOG(OCF } \\
)\end{array}$ & -0.006221 & 0.04034 & -0.154211 & 0.8778 \\
\hline & \multicolumn{2}{|c|}{ Effects S pecification } & & \\
\hline & & & S.D. & Rho \\
\hline \multicolumn{3}{|c|}{ Cross-section random } & 0.584195 & 0.7569 \\
\hline \multicolumn{3}{|c|}{ Idiosyncratic random } & 0.331042 & 0.2431 \\
\hline & \multicolumn{2}{|c|}{ Weighted S tatistics } & & \\
\hline R-squared & 0.556497 & \multicolumn{2}{|c|}{ Mean dependent var } & 1.16489 \\
\hline $\begin{array}{l}\text { Adjusted R- } \\
\text { squared }\end{array}$ & 0.534863 & \multicolumn{2}{|c|}{ S.D. dependent var } & 0.49141 \\
\hline $\begin{array}{l}\text { S.E. of } \\
\text { regression }\end{array}$ & 0.335149 & \multicolumn{2}{|c|}{ Sum squared resid } & 9.21065 \\
\hline F-statistic & 25.72289 & \multicolumn{2}{|c|}{ Durbin-Watson stat } & 2.00639 \\
\hline \multirow[t]{2}{*}{$\begin{array}{l}\text { Prob(F- } \\
\text { statistic) }\end{array}$} & $\mathbf{0}$ & & & \\
\hline & \multicolumn{2}{|c|}{ Unweighted $S$ tatistics } & & \\
\hline R-squared & 0.714073 & \multicolumn{2}{|c|}{ Mean dependent var } & 3.74628 \\
\hline $\begin{array}{l}\text { Sum } \\
\text { squared } \\
\text { resid }\end{array}$ & 37.98035 & \multicolumn{2}{|c|}{ Durbin-Watson stat } & 0.94612 \\
\hline
\end{tabular}

Table 5 above depicts the model 01 summary computed for the period of 2011 to 2015. It contained 87 balanced observations. 29 cross sections were included in this summary. The weighted $\mathrm{R}$ squared for this model was $55.6 \%$ and the adjusted R squared was $53.4 \%$. According to the $\mathrm{F}$ statistic the overall model was statistically significant at $1 \%$ level. The 
Durbin-Watson statistic of this model was 2.00. Which implied that the model was free from autocorrelation. LOG (EPS) was statistically significant at 5\% level. LOG (BVE) variable was statistically significant at $1 \%$ level and both have a positive relationship with the LOG (MVPS). LOG (OCF) was not statistically significant in this model also, however it has a negative association with LOG (MVPS). LOG (LEV) has a negative relationship between LOG (MVPS) which was also not statistically significant at $5 \%$ level.

\section{Model 02- Pre IFRS and Post IFRS combined}

Pre-IFRS and Post-IFRS samples were combined and "Combined" model was formed and the results from regression was summarized in the below table 6 .

Table 6 Summary of regression result (Model 2) (2009-2015)

\begin{tabular}{|c|c|c|c|c|}
\hline Variable & Coefficient & Std. Error & t-Statistic & Prob. \\
\hline $\mathrm{C}$ & 2.239502 & 0.203809 & 10.98823 & 0 \\
\hline LOG(EPS) & 0.145912 & 0.033745 & 4.323894 & 0 \\
\hline LOG(BVE) & 0.49038 & 0.064224 & 7.635443 & 0 \\
\hline LOG(LEV) & 0.007605 & 0.02407 & 0.31594 & 0.7524 \\
\hline LOG(OCF) & -0.020346 & 0.034061 & -0.59735 & 0.551 \\
\hline \begin{tabular}{|c|} 
IMPACT $^{\star} \mathrm{L}$ \\
OG(EPS)
\end{tabular} & 0.047046 & 0.050699 & 0.927959 & 0.3546 \\
\hline $\begin{array}{c}\text { IMPACT }^{\star} \mathrm{L} \\
\text { OG(BVE) }\end{array}$ & -0.090124 & 0.027088 & -3.32709 & 0.001 \\
\hline $\begin{array}{l}\text { IMPACT }^{*} \mathrm{~L} \\
\mathrm{OG}(\mathrm{OCF})\end{array}$ & 0.065676 & 0.047753 & 1.375336 & 0.1706 \\
\hline & Weighted & Statistics & & \\
\hline R-squared & 0.411008 & \multicolumn{2}{|c|}{ Mean dependent var } & 1.2667 \\
\hline $\begin{array}{l}\text { Adjusted } \\
\text { R-squared }\end{array}$ & 0.389864 & \multicolumn{2}{|c|}{ S.D. dependent var } & 0.5757 \\
\hline $\begin{array}{l}\text { S.E. of } \\
\text { regressio } \\
n\end{array}$ & 0.449709 & \multicolumn{2}{|c|}{ Sum squared resid } & 39.436 \\
\hline F-statistic & 19.43914 & \multicolumn{2}{|c|}{ Durbin-Watson stat } & 1.7439 \\
\hline $\begin{array}{l}\text { Prob(F- } \\
\text { statistic) }\end{array}$ & 0 & & & \\
\hline
\end{tabular}

Table 6 shows the summary of model 2 or the combined model computed for the period of 2009 to 2015. It contains 203 balanced observations. 29 cross sections were included in this summary. The $\mathrm{R}$ squared for this model was $41.10 \%$ and the adjusted $\mathrm{R}$ squared was $38.99 \%$. The $\mathrm{F}$ statics value was 19.43 and the corresponding probability $(\mathrm{p})$ value of $\mathrm{F}$ statistic showed that the overall model is statistically significant at $1 \%$ level. The Durbin-Watson statics of this model was 1.74 which was very much closer to 2 , implied that the model was free from autocorrelation. LOG (EPS) was statistically significant at $1 \%$ level. LOG (BVE) variable was statistically significant at $1 \%$ level and both variables had a positive relationship with LOG (MVPS). LOG (OCF) was not statistically significant in this model as well. However it have a negative association with LOG (MVPS). LOG (LEV) also had a positive relationship between LOG (MVPS) which was not statistically significant at 5\% level as well.

The Impact of IFRS adoption on the independent variables were denoted by the interactive variables "IMPACT*LOG (EPS), IMPACT*LOG (BVE) and IMPACT*LOG (LEV). However, none of these variables were significant in this model at $5 \%$ and $10 \%$ significant levels except for LOG (BVE). The negative coefficient value indicated a negative relationship between the IFRS adjusted book value of equity and the market price of Shares of Manufacturing companies but the coefficient value is not powerful enough to draw any conclusion about the value. Therefor we can conclude that the IFRS adjusted earnings, book value of equity and operating cash flow do not have any statistically significant impact on the market price of shares in listed manufacturing entitles in Sri Lanka. 


\section{Discussion, Conclusion and Recommendations}

The results are in line with the previous research done by Ames, (2013) he concludes that the quality of accounting numbers stated in South Africa remained relatively unchanged before and after IFRS adoption. Similarly, according to Paananen, (2008), there was no increase in financial reporting quality over the first 2 years after the IFRS adoption in Sweden. Alabede et al., (2016) found that the IFRS adoption has not caused any significant enhancement in value relevance of accounting information of the nonfinancial firms on Nigerian Stock Exchange. Habib and Weil, (2008) also failed to find out any significant growth in the aggregate value relevance of accounting information in the postregulation period with referring to New Zealand. Same results were found on Greece by Tsalavoutas et al., (2012) who found that there was no significant change in the value relevance measures of accounting quality before and after the mandatory adopting of IFRS.

\section{Conclusion}

In this study, an effort was made to discover the impact of IFRS adoption on quality of accounting information in Sri Lanka. All the listed companies in Sri Lanka was mandated to apply SLFRS, which is almost identical to IFRS with effect from the beginning of 2012 under a special gazette notice. In order to find whether this adoption has a significant impact on quality of accounting information, value relevance was used as the indicator after considering prior literature. Listed manufacturing companies were selected as the sample to perform the study and the sample consists of 29 companies listed o Colombo Stock Exchange (CSE). Financial information for two periods that is from 2009-2011 and
2013-2015 was used for this study as preIFRS and post-IFRS periods.

Panel Regression analysis showed, the quality of accounting information was not significantly improved in terms of value relevance in the post-IFRS period of the listed manufacturing companies in Sri Lanka. Furthermore, when considering the individual variables such as Earnings, Book value of Equity, Operating cash flows did not show any impact with the introduction of IFRS of listed manufacturing companies. This finding was in line with the previous literature worldwide.

When comparing the accounting standards issued with the IFRS adoption and previous LKAS and SLAS standards which were in operation before the IFRS adoption, there were no material changes in the content of two standards but the respective standard name and number was changed. For an example "SLAS 09- Cash Flow Statements" was replaced by "LKAS 07- Statement of Cash Flows". There were no any impact from this change to the accounting figures except the change in the name and the number. However with the IFRS adoption there were new standards introduced by replacing the previous standards such as "SLFRS/IFRS 02- Share Based Payments", "LKAS/IAS 19-Employee Benefits", "SLFRS/IFRS 04- Insurance Contracts" and most importantly "LKAS/IAS 39- Financial Instruments:Recognition and Measurement" with these standards the classification of line items, fair value and impairment adjustments, restatement of useful life of Property Plant and Equipment were adjusted to the accounting figures in the Financial statements of the selected manufacturing companies, however these adjustments are not materially significant to change the quality of accounting information with IFRS adoption referring to the value 
relevance of the listed manufacturing companies in Sri Lanka.

\section{Recommendations}

Based on the information gathered from this study some recommendations can be put forward to retain the quality of accounting information in Sri Lanka in a superior level. Regulatory institutions such as CA Sri Lanka should concurrently review the existing accounting standards used in Sri Lanka with global accounting standards and should make necessary revisions in a timely manner. This will ensure that the quality of accounting standards remains consistent over time.

Continuous seminars and workshops have to be conducted by CA Sri Lanka for accounting professionals, Undergraduates and other students who study about accounting as a subject for their academic work. There were extensive seminars and workshops conducted during the year of 2012-2015 period for the above target groups and this rapport should be further continued to make the target group aware about the accounting standards and their revisions. In order to maintain the quality of accounting information, the accounting information reported through annual reports should be reviewed by regulatory bodies thoroughly. At presently the annual reports of the companies in Sri Lanka are reviewed and audited by independent audit firms. Sri Lanka Accounting and Auditing Standards Monitoring Board (SLAASMB) is the legal entity in Sri
Lanka to monitor the compliance with Sri Lankan Accounting and Auditing Standards of the economically significant business enterprises.

\section{Limitations of the Study and Future Research}

This Study was conducted using 29 listed manufacturing companies in Colombo Stock Exchange- Sri Lanka in which, the sample was limited to listed manufacturing companies in Sri Lanka only. A larger population with cross country representation could provide better results about the quality of accounting information with the IFRS adoption. Another limitation of this research can be considered as the inability of controlling the macroeconomic variables which can be adversely affect the outcomes of this study. The quality of accounting information was measured through value relevance method. However, there are other ways of measuring the quality of accounting information such as earnings management and timely loss recognition. Further research are recommended on this area by considering a larger sample size covering different sectors in the Colombo stock exchange for a longer time period by considering different indicators of quality of accounting information. Furthermore, a survey can be conducted among the users of the accounting information to derive their perception on the impact to the quality of accounting information with the IFRS adoption. 


\section{References}

Alabede, J., FCA, Fcti, 2016. Impact of Accounting Standards on the Value Relevance of Accounting Information from Nigeria's Listed Firms: Comparative Study of Pre- and Post IFRS Adoption.

Alfaraih, M., 2009. Compliance with international financial reporting standards (IFRS) and the value relevance of accounting information in emerging stock markets : evidence from Kuwait (Thesis). Queensland University of Technology.

Ames, D., 2013. IFRS adoption and accounting quality: The case of South Africa. Journal of Applied Economics and Business Research 3, 154-165.

Arum, E.D.P., 2013. Implementation of International Financial Reporting Standards (IFRS) and the Quality of Financial Statement Information in Indonesia. Research Journal of Finance and Accounting 4, 200-209.

Ashbaugh, H., Pincus, M., 2001. Domestic Accounting Standards, International Accounting Standards, and the Predictability of Earnings. Journal of Accounting Research 39, 417-434.

Ball, R., 2006. International Financial Reporting Standards (IFRS): pros and cons for investors. Accounting and Business Research 36, 5-27.

Barth, M.E., Landsman, W.R., Lang, M.H., 2008. International Accounting Standards and Accounting Quality. Journal of Accounting Research 46, 467-498.

Ben Othman, H., Kossentini, A., 2015. IFRS adoption strategies and theories of economic development: Effects on the development of emerging stock markets. Journal of
Accounting in Emerging Economies $5,70-121 .$.

Brüggemann, U., Daske, H., Homburg, C., Pope, P.F., 2012. How do Individual Investors React to Global IFRS Adoption? (SSRN Scholarly Paper No. ID 1458944). Social Science Research Network, Rochester, NY.

Callao, S., Jarne, J.I., Laínez, J.A., 2007. Adoption of IFRS in Spain: Effect on the comparability and relevance of financial reporting. Journal of International Accounting, Auditing and Taxation 16, 148-178.

Cascino, S., Gassen, J., 2010. Mandatory IFRS adoption and accounting comparability. SFB 649 discussion paper.

Chen, H., Tang, Q., Jiang, Y., Lin, Z., 2010. The Role of International Financial Reporting Standards in Accounting Quality: Evidence from the European Union. Journal of International Financial Management \& Accounting 21, 220-278.

Devalle, A., Onali, E., Magarini, R., 2010. Assessing the Value Relevance of Accounting Data After the Introduction of IFRS in Europe. Journal of International Financial Management \& Accounting 21, 85119.

Edward Lee, M.W. and C. (Colin) Z., 2013. Does IFRS Convergence Affect Financial Reporting Quality in China? ACCA 29 Lincoln?s Inn Fields London WC2A 3EE United Kingdom 1: The Association of Chartered Certified Accountants; 2013. Report No. 131.

Erin, O., Olojede, P., Ogundele, O., Erin, O., Olojede, P., Ogundele, O., 2017. Value Relevance of Accounting Data in the Pre and Post 
IFRS Era: Evidence from Nigeria. International Journal of Finance and Accounting 6, 95-103.

Goel, A.M., Thakor, A.V., 2003. Why Do Firms Smooth Earnings? The Journal of Business 76, 151-192. https://doi.org/10.1086/344117

Habib, A., Weil, S., 2008. The impact of regulatory reform on the valuerelevance of accounting information: Evidence from the 1993 regulatory reforms in New Zealand. Advances in Accounting 24, 227-236.

Healy, P.M., Wahlen, J.M., 1999. A Review of the Earnings Management Literature and Its Implications for Standard Setting. Accounting Horizons 13, 365-383.

Hung, M., 2007. Financial statement effects of adopting international accounting standards: The case of Germany [WWW Document].

Iatridis, G., 2010. International Financial Reporting Standards and the quality of financial statement information. International Review of Financial Analysis 19, 193-204.

IFRS Foundation, 2017c. IFRS Conceptual Framework - Conceptual Framework [WWW Document]. URL http://www.ifrs.org/projects/workplan/conceptual-framework/ (accessed 10.3.17).

JenicePrather-Kinsey, S.W., 2005. IAS Versus U.S. GAAP: Assessing the Quality of Financial Reporting in South Africa, the United Kingdom, and the United States. Advances in International Accounting 18, 153168.

Jermakowicz, E.K., GornikTomaszewski, $\quad$ S., 2006. Implementing IFRS from the perspective of EU publicly traded companies. Journal of International Accounting, Auditing and Taxation 15, 170-196.

Kaaya, I.D., 2015. The Intenational Financial Reporting Standards (IFRS) and Value Relevance: A Review of Empirical Evidence. Journal of Finance and Accounting, Journal of Finance and Accounting 3, 37-46.

Lang, M., Smith Raedy, J., Wilson, W., 2006. Earnings management and cross listing: Are reconciled earnings comparable to US earnings? Journal of Accounting and Economics 42, 255-283.

Morais, A.I., Curto, J.D., 2008. Accounting quality and the adoption of IASB standards: Portuguese evidence. Revista Contabilidade \& Finanças 19, 103-111.

Mulenga, $\quad$ M.J., 2016. INTERNATIONAL FINANCIAL REPORTING

STANDARDS'ADOPTION AND

VALUE RELEVANCE OF ACCOUNTING INFORMATION: A BRIEF LITERATURE REVIEW. 2016 International Journal of Economics, Commerce and Management.

N., K., Hevas, D., 2009. The Effect of the Mandatory Application of IFRS on the Value Relevance of Accounting Data: Some Evidence from Greece. European Research Studies Journal XII, 73-100.

Olfa, B.J., Hamadi, M., 2015. The Impact of the IAS/IFRS Adoption on the Predictive Quality of Discretionary Accruals: A Comparison between the French and the British Context. International Journal of Economics and Finance 7, 208. 
Outa, E.R., 2011. The Impact of International Financial Reporting Standards (IFRS) Adoption on The Accounting Quality of Listed Companies In Kenya. International Journal of Accounting and Financial Reporting 1, 212-241.

Paananen, M., 2008. The IFRS Adoption's Effect on Accounting Quality in Sweden (SSRN Scholarly Paper No. ID 1097659). Social Science Research Network, Rochester, NY.

Paglietti, P., 2010. Earnings management, timely loss recognition and value relevance in Europe following the IFRS mandatory adoption: evidence from Italian listed companies. Economia Aziendale Online 1, 97-117.

Papadatos, K., Bellas, A., 2011. The Value Relevance of Accounting Information Under Greek and International Financial Reporting Standards: The Influence of FirmSpecific Characteristics (SSRN Scholarly Paper No. ID 1963369). Social Science Research Network, Rochester, NY.

Qu, W., Fong, M., Oliver, J., 2012. Does IFRS convergence improve quality of accounting information?Evidence from the Chinese stock market. Corporate ownership and control 9, 187-196.

Samir M. El-Gazzar, Philip M. Finn, 2017. Restatements and accounting quality: a comparison between IFRS and US-GAAP. $J$ of Fin Report and Acc 15, 39-58.

Shima, K.M., Yang, D.C., 2012. Factors affecting the adoption of IFRS. International Journal of Business 17, 276.
Suadiye, G., 2012. Value Relevance of Book Value \& Earnings Under the Local GAAP and IFRS: Evidence from Turkey. Ege Academic Review $12,301-310$.

Tendeloo, B. van, Vanstraelen, A., 2005. Earnings management under German GAAP versus IFRS. European Accounting Review 14, 155-180.

Tsalavoutas, I., André, P., Evans, L., 2012. The transition to IFRS and the value relevance of financial statements in Greece. The British Accounting Review 44, 262-277.

Udayakumara, K.G.A., Weerathunga, P.R., 2015. Does mandatory adoption of international financial reporting standards (IFRS/SLFRS) deter the earnings management of Sri Lankan firms?

Weerathunga, P.R., 2015. The Impact of International Financial Reporting Standards adoption on Accounting Quality: Evidence From Sri Lanka.

Weerathunga, P.R., Udaya Kumara, K.G.A., 2015. The Impact of International Financial Reporting Standards Convergence on Accounting Quality. 


\section{Appendices}

\section{Appendix A}

Table 1 Descriptive Statistics table of pre-IFRS data (2009-2011)

\begin{tabular}{|l|c|r|r|r|r|}
\hline & LOG(MVPS) & LOG(EPS) & LOG(BVE) & LOG(LEV) & LOG(OCF) \\
\hline Mean & 3.868337 & 0.585926 & 3.081513 & -1.373621 & 0.963602 \\
\hline Median & 3.988984 & 0.828552 & 3.298537 & -1.214023 & 1.252763 \\
\hline Maximum & 5.872118 & 3.457263 & 5.377567 & 1.561507 & 5.365976 \\
\hline Minimum & 0.641854 & -4.605170 & 0.332177 & -6.907755 & -5.809143 \\
\hline Std. Dev. & 1.156246 & 1.775671 & 1.238966 & 1.649480 & 1.985460 \\
\hline
\end{tabular}

\section{Appendix B}

Table 2 Descriptive Statistics table of post-IFRS data (2013-2015)

\begin{tabular}{|l|l|l|l|l|l|}
\hline & LOG(MVPS) & LOG(EPS) & LOG(BVE) & LOG(LEV) & LOG(OCF) \\
\hline Mean & 3.746280 & 1.000173 & 3.265982 & -1.218082 & 0.928632 \\
\hline Median & 4.075841 & 1.163151 & 3.665099 & -1.024433 & 1.143267 \\
\hline Maximum & 5.907267 & 3.415429 & 5.147669 & 0.592774 & 4.077215 \\
\hline Minimum & 0.336472 & -5.809143 & 0.029559 & -4.017384 & -3.352407 \\
\hline Std. Dev. & 1.242803 & 1.688552 & 1.280374 & 0.944907 & 1.713217 \\
\hline
\end{tabular}

\section{Appendix C}

Table 3 Descriptive Statistics table of pre-post IFRS data (2009-2015)

\begin{tabular}{|l|l|l|l|l|l|l|}
\hline & LOG(MVPS) & LOG(EPS) & LOG(BVE) & LOG(LEV) & LOG(OCF) & IMPACT \\
\hline Mean & 3.781522 & 0.774707 & 3.139616 & -1.420337 & 0.978048 & 0.438424 \\
\hline Median & 4.007333 & 0.920283 & 3.411247 & -1.164752 & 1.184484 & 0.000000 \\
\hline Maximum & 5.907267 & 3.457263 & 5.377567 & 3.882388 & 5.366149 & 1.000000 \\
\hline Minimum & 0.336472 & -5.809143 & -2.055725 & -6.907755 & -5.809143 & 0.000000 \\
\hline Std. Dev. & 1.180368 & 1.738257 & 1.306284 & 1.855717 & 1.822336 & 0.497421 \\
\hline
\end{tabular}

